\title{
The Effects of Motivation, Compensation, and Work Environment on the Performance of Local Public Officer
}

\author{
Sukriyani \\ Faculty of Economics, Universitas Terbuka, Indonesia \\ sukriyanisugeng75@gmail.com,530022546@ecampus.ut.ac.id
}

\begin{abstract}
The aim of this research was to find out and analyze the effects of motivation, compensation, and work environment on the performance of local public officers in the Yapen Islands Regency government environment. This research used a quantitative method and an instrument in the form of a questionnaire. Using the purposive sampling technique, 143 respondents were selected from four local government agencies in the Yapen Islands Regency. The SPSS statistical program was used to analyze data. The analysis methods used were descriptive analysis, validity and reliability tests, classical assumption test, and multiple linear regression analysis. The results show that compensation had a positive effect on the performance of local public officers in the Yapen Islands Regency. On the other hand, the variables motivation and work environment did not have any effect on the performance of local public officers in the Yapen Islands Regency.
\end{abstract}

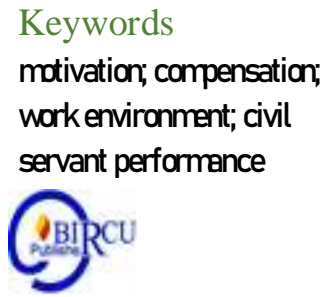

Keywords

motivation; compensation; work environment; civil servant performance

\section{Introduction}

The state civil administration (ASN) is one of the important elements of government management and state development in the effort to achieve national goals (Sudrajat et al., 2019). According to Law No. 5 of 2014, the state civil administration is a civil servant responsible for public service for the realization of community welfare. Reliable civil servant performance in public service is expected by the community (Mustafid, 2017).

Recently, civil servant performance has grown into a strategic issue due to serious complaints regarding public service, both in the economic and political sectors (Wahyudi et al., 2020). Based on the data from the Employment and Human Resources Development Agency of the Yapen Islands Regency, the phenomenon today is low performance and service quality, which is linked to civil servant professionalism, especially that of class II local public officers of the Yapen Islands Regency. The issue of officer performance in the Yapen Islands Regency remain problematic, necessitating further investigation of its causing factors.

According to Marwansyah (2014), performance problems in an organization or institution can be caused by numerous factors, such as knowledge or skills, supporting work environment, technological resources, and work motivation. In earlier studies, researchers have encountered differences in research findings, which are also referred to as research gap.

The research by Mukti (2015) showed that work environment, compensation, and motivation had positive effects on the performance of local public officers in the Madani Regional Hospital of the Central Sulawesi Province. The research by Dhermawan et al. 
(2012) separately concluded that motivation and work environment did not have any positive effects on ASN performance, while compensation did. Meanwhile, Wahyudi et al. (2020) concluded that work environment and motivation significantly influenced ASN performance.

Another study by Murni and Heryanto (2019) showed that motivation and compensation positively affected employee performance, while environment did not have any effect. On the other hand, Dharmanegara et al. (2016) demonstrated that work motivation did not have any influence on employee performance.

According to Kuranchie-Mensah and Amponsah-Tawiah (2016), motivation influences employee performance, in which case the level of employee performance would depend on the driving force of an employee. Motivation is largely linked to the employee's own person, the way he/she works, and his/her work outcomes (Jacobsen et al., 2014). From the interviews and field observation it was found that the motivation of the local public officers in the Yapen Islands Regency still scored low. This was proven by the local public officers late arrival at the office, premature departure from the office, inaccuracy in the works generated, low work ethics that led to absence, and lack of awareness of their role as servants of the community.

Results of interviews with class II local public officers in the Yapen Islands Regency reveal that the low motivation of the officers was caused by their rare involvement in works, activities, and trainings (BIMTEK) and lack of open communication between leaders and subordinates. As a result, they felt an absence of appreciation at work which was supposed to motivate them to work hard, causing them discomfort at the office. Their attendance level was also considered minimal, which led to suboptimal performance.

Other than motivation, compensation also influences civil servant performance (Murni \& Heryanto, 2019). As defined by Hasibuan (2014), compensation is all income in the form of cash and articles directly and indirectly received by employees as reward for the services they provided their companies with. The compensation system has a potential as the most important means in shaping behaviors and influencing performance (Widasih et al., 2019). Satisfaction with financial compensation can grow strong motivation, causing employees to be willing to dedicate themselves and to be actively involved in their work (Kusumayuda, 2019).

Based on the results of the preliminary survey and interviews with local public officers in the Yapen Islands Regency, the compensation received was still considered low. Many class I and II local public officers complained and protested that they received less salary than central public officers, and the uang lauk pauk (allowance for side dishes) received was too small (Rp20,000 per day). Additionally, frequent reoccurrence of late payments was also reported. This shows that employee compensation deserves a greater amount of attention.

The next factor that can also influence local public officers performance is work environment. Work environment is anything that exists around an employee and influences $\mathrm{him} / \mathrm{her}$ in performing the tasks assigned to him/her (Sedarmayanti, 2009). As pointed out by Lee and Brand (2005), the work environment in an organization is expected to be able to provide support for performance.

Results of the preliminary survey and interviews indicate that the work environments of local government agencies (OPD) of the Yapen Islands Regency still belonged to the low category and thus needed an improvement in working comfort. Employees at the Anatourei Sub-district office complained about the following points of uncomfortable work environment: the office was small and cramped; not all employees have their own seats; there was no room air conditioning; and no adequate facilities and infrastructure 
were available. The same was also reported regarding the work environment of the Women Empowerment, Child Protection, and Family Planning Social Office. Non-conducive work environment due to small and cramped office and unavailability of a sufficient store room that leaves the impression of disorder and mess caused discomfort at work.

Based on the research gap found and the results of the preliminary survey and interviews, it could be concluded that motivation, compensation, and work environment influenced the performance of local public officers in the Yapen Islands Regency. The motivation of local public officers in the Yapen Islands Regency and the compensation received were low, and the work environments were less than conducive. It thus became an interest to the researchers to investigate the effects of motivation, compensation, and work environment on the performance of local public officers in the Yapen Islands Regency government environment. The aim of this research was to figure out and analyze the effects of motivation, compensation, and work environment on the performance of local public officers in the Yapen Islands Regency government environment.

\section{Review of Literatures}

\subsection{Performance}

According to As'ad (2004), performance is the outcome one achieves based on the measure applicable for the relevant work. A company applies certain criteria for a certain period in assessing its employees' performance. Performance is a function of motivation and the ability to complete a task or work, in which case one should have a given degree of willingness and ability (Rivai \& Sagala, 2005).

Performance is a system used to assess and figure out whether an employee has completed his/her work entirely. It is a combination of work outcome (what one must achieve) and competency (how he/she achieves it) (Sedarmayanti, 2009). Meanwhile, based on Wirawan's definition (2009), performance is the outcomes generated by the functions or indicators of a work or a profession for a certain time.

Performance is the estuary and organizational culture is the base, while work motivation, job satisfaction is between the beginning and end. The meaning of the beginning and the end meant is that the initial variable influences the final variable, while the variable between the beginning and end is the interpending variable. Performance can be achieved well if the principal performs the main tasks, functions, and responsibilities have the ability or competence in leadership (Arif et al, 2019).

\subsection{Motivation}

Motivation is an encouragement that makes people want to work or act in a certain way. Speaking of motivational matters, what is discussed is human needs (Ningsih, 2018). As defined by Mathis and Jackson (2006), motivation is something which causes, channels, and supports a human being's behaviour for him/her to work hard and to be enthusiastic about achieving an optimal outcome. In the opinion of Greenberg and Baron (2003), meanwhile, motivation is a set of processes which arouse, direct, and maintain one's behaviour toward a goal achievement.

Work motivation is something which produces a force or spirit for work, otherwise put as the driver of work spirit (Martoyo, 2007). Motivation is a psychological process which arouses and directs goal achievement behavior (goal-directed behavior) (Kreitner \& Kinicki, 2001)

With motivation, one is expected to keep striving to raise a spirit and discipline in work for the achievement of the organization's goals (Permadi et al., 2018). One's level of 
motivation will drive his/her willingness to exhibit a behaviour or determine how fast he/she will complete a task (Murni \& Heryanto, 2019). Previous research by Candradewi and Wahyudi et al. (2020), Wardani and Riyanto (2019), Dewi (2019), Marcy et al. (2018), and Suharno et al. (2017) showed that there was a positive relationship between motivation and employee performance. Therefore, referring to previous empirical findings, the first hypothesis proposed is as follows:

H1: Motivation has a positive effect on the performance of local public officers in the Yapen Islands Regency

\subsection{Compensation}

Compensation is something which is received by an employee in place of his/her service contribution to a company (Rivai \& Sagala, 2005). Compensation payment is the implementation of a human resources management function related to all manners of appreciation for an individual as an exchange for completing an organizational task (Rivai \& Sagala, 2005). Compensation for an employee is a measure for his/her work success. It is both a monetary and a non-monetary service received by an employee (Davis \& Newstrom, 1995).

Murni and Heryanto (2019) in their research concluded that if an employee receives compensation in a sufficient amount in correspondence with what he/she has performed for a company, he/she will tend to do his/her best for the company, and, thus, he/she will make efforts to maintain or even improve his/her performance at the company. Moreover, as reported by Mukhlidah and Aktif (2020), Akbar et al. (2020), Candradewi and Dewi (2019), and Kadarisman (2019), there is a positive relationship between compensation and employee performance. Therefore, referring to previous empirical findings, the second hypothesis proposed is as follows:

H2: Compensation has a positive effect on the performance of local public officers in the Yapen Islands Regency

\subsection{Work Environment}

Work environment is anything that exists around an employee and influences $\mathrm{him} / \mathrm{her}$ in performing the tasks assigned to him/her (Nitisemito, 2005). An employee who works in a work environment which supports him/her to work optimally will generate a good performance. Conversely, if he/she works in a non-conducive environment and in a condition which is unsupportive for him to work optimally, he/she will be unmotivated and neglect his/her responsibilities, leading to a lowered performance (Kusriyanto, 1991). A physical work environment is said good if the employees in an institution are able to perform all their activities optimally, well, safely, and comfortably.

The research by Bakhri et al. (2015) concluded that the creation of a work environment which supports work productivity will make employees comfortable, impacting on their initiative to complete their works. Besides, previous research by Wahyudi et al. (2020), Diamantidis and Prodromos (2019), Prabowo et al. (2019), Kurniawan and Heryanto (2019), and Wardani and Riyanto (2019) showed a positive relationship between work environment and employee performance. Therefore, referring to previous empirical findings, the third hypothesis proposed is as follows:

H3: Work environment has a positive effect on the performance of local public officers in the Yapen Islands Regency

The three hypotheses proposed are then summarized in the following research model (Figure 1). 


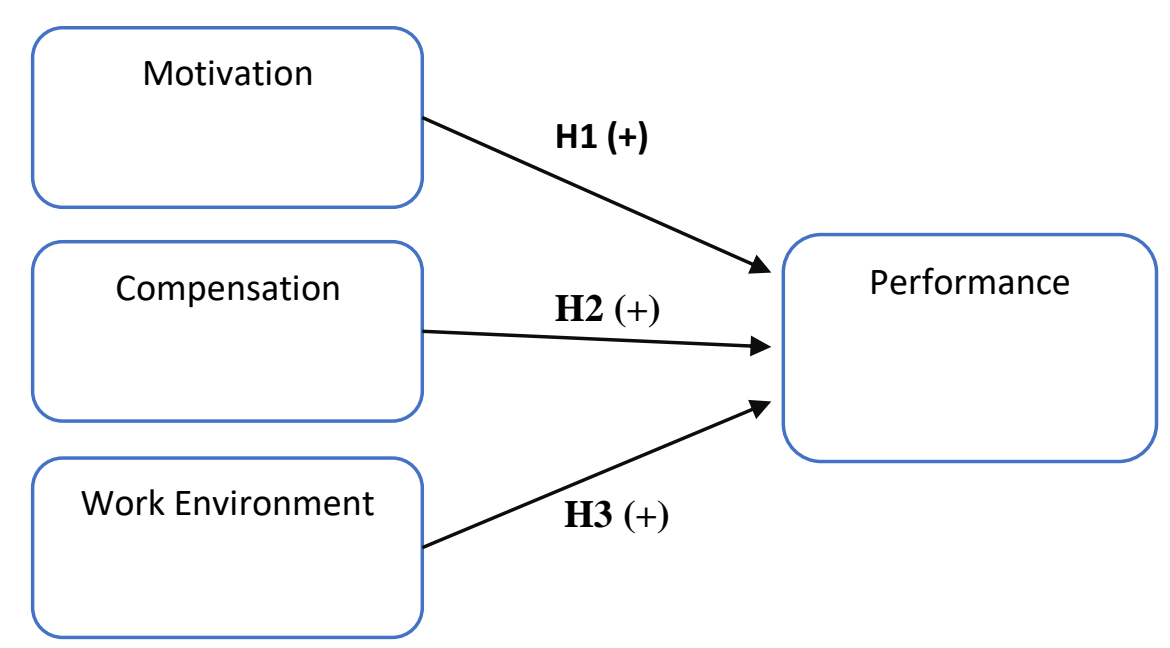

Figure 1. Research Model

\section{Research Methods}

This research is a quantitative study with an emphasis on objective measurement aspects against a social phenomenon. The population of this research was class II local public officers from four local government agencies - the Agriculture and Food Security Office, the Social Office, and the Women Empowerment, Child Protection, and Family Planning Office of South Yapen District and the Anatourei Subdistrict Office. Purposive sampling technique was used in the sampling process, from which 143 respondents were selected.

Data were collected through a questionnaire with a 5-point Likert scale, which is detailed as follows: 5-extremely good, 4-good, 3-fair, 2-bad, and 1-extremely bad. Interviews were involved to analyze the drivers and hindrances faced by class II local public officers in the Yapen Islands Regency in such phenomena as employee motivation, work environment, and compensation (salary/wage), to name a few. The SPSS statistical program was used to analyze data. The analysis methods used included descriptive analysis, validity and reliability tests, classical assumption test, and multiple linear regression analysis. The dependent variable in this research was local public officers performance, while the independent variables were motivation, compensation, and work environment. 


\section{Results and Discussion}

The respondents in this research had varied background characteristics in themselves. The focus of this research was on. Data on the respondents' described characteristics are presented in Table 1.

Table 1. Respondents' Characteristics Description

\begin{tabular}{lccc}
\hline Categories & Answer Alternatives & $\begin{array}{c}\text { Number of } \\
\text { Respondents }\end{array}$ & $\begin{array}{c}\text { Percentages } \\
(\%)\end{array}$ \\
\hline Gender & Male & 86 & $60.14 \%$ \\
\hline \multirow{3}{*}{ Latest Education } & Female & 57 & $39.86 \%$ \\
& Junior High School & 2 & $1.4 \%$ \\
& Senior High School & 128 & $89.5 \%$ \\
Age & D3 & 13 & $9.1 \%$ \\
\hline \multirow{3}{*}{ Number of Years } & $31-40$ Years & 60 & $41.9 \%$ \\
Worked & $40-50$ Years & 58 & $40.6 \%$ \\
& $51-57$ Years & 25 & $17.5 \%$ \\
\hline & $1-5$ Years & 68 & $47.5 \%$ \\
Local Public & $11-15$ Years & 18 & $12.6 \%$ \\
Officers & $16-20$ Years & 31 & $21.7 \%$ \\
Title/Group & II.a & 26 & $18.2 \%$ \\
& II.b & 19 & $13.3 \%$ \\
\hline
\end{tabular}

Based on Table 1, the majority of the respondents were male $(60.14 \%)$, graduates of senior high schools $(89.5 \%)$, and aged between 31 and 40 years $(41.9 \%)$. The respondents were mostly of class II.b (53.1\%) with working experience of $1-5$ years $(47.5 \%)$.

Descriptive analysis was then used to describe the conditions and characteristics of the answers of the respondents for each construct or variable studied. The analysis results were to be used to identify the tendency of the respondents' answers for each variable studied. The variable motivation consisted of 10 indicators, compensation 5 indicators, work environment 10 indicators, and employee performance 8 indicators.

The respondents' answers were categorized using an interval scale which was calculated by dividing by five the deduction of the minimum score from the maximum score. From the calculation, an interval of 0.80 was obtained. According to Sugiyono (2013), with an interval of 0.80 , the categorization system was as follows: $1.00-1.80$ (very low); 1.81-2.60 (low); 2.61-3.40 (fair); 3.41-4.20 (high); and 4.21-5.00 (very high). 
Table 2. Respondents' Opinions Distribution

\begin{tabular}{|c|c|c|c|c|c|c|c|c|c|}
\hline \multicolumn{2}{|r|}{ Items } & \multicolumn{5}{|c|}{ Opinion Alterntaives } & \multirow[t]{3}{*}{ Total } & \multicolumn{2}{|c|}{ Means Categori } \\
\hline & & VB & $\mathrm{B}$ & $\mathrm{F}$ & $\mathrm{G}$ & VG & & & es \\
\hline & & 5 & 4 & 3 & 2 & 1 & & & \\
\hline X1.1 & $\begin{array}{l}\text { The salary } \\
\text { accepted is as } \\
\text { expected }\end{array}$ & 0 & 10 & 88 & 45 & 0 & 143 & 2.76 & Fair \\
\hline $\mathrm{X} 1.2$ & $\begin{array}{l}\text { The salary accepted } \\
\text { currently allows for } \\
\text { the performance of } \\
\text { the work }\end{array}$ & 0 & 12 & 83 & 48 & 0 & 143 & 2.75 & Fair \\
\hline $\mathbf{X} 1.3$ & $\begin{array}{l}\text { There is a sense of } \\
\text { security during work }\end{array}$ & 0 & 45 & 88 & 10 & 0 & 143 & 3.24 & Fair \\
\hline X1.4 & $\begin{array}{l}\text { The relationship } \\
\text { between employees } \\
\text { is well established }\end{array}$ & 5 & 36 & 97 & 5 & 0 & 143 & 3.29 & Fair \\
\hline X1.5 & $\begin{array}{l}\text { The relationship } \\
\text { with the leaders is } \\
\text { well established }\end{array}$ & 1 & 32 & 89 & 21 & 0 & 143 & 3.09 & Fair \\
\hline X1.6 & $\begin{array}{l}\text { The leaders } \\
\text { provide facilities } \\
\text { for self- } \\
\text { development }\end{array}$ & 0 & 3 & 73 & 47 & 20 & 143 & 2.41 & Fair \\
\hline X1.7 & $\begin{array}{l}\text { The leaders provide } \\
\text { opportunities for } \\
\text { expressing } \\
\text { creativity during } \\
\text { work }\end{array}$ & 0 & 11 & 64 & 45 & 23 & 143 & 2.44 & Fair \\
\hline X1.8 & $\begin{array}{l}\text { The leaders provide } \\
\text { encouragement and } \\
\text { motivation }\end{array}$ & 0 & 20 & 51 & 45 & 27 & 143 & 2.45 & Fair \\
\hline X1.9 & $\begin{array}{l}\text { There is the ability } \\
\text { to work optimally } \\
\text { and to complete the } \\
\text { work }\end{array}$ & 12 & 106 & 23 & 2 & 0 & 143 & 3.90 & High \\
\hline X1.10 & $\begin{array}{l}\text { Appreciation can } \\
\text { motivate to work } \\
\text { hard }\end{array}$ & 15 & 91 & 30 & 7 & 0 & 143 & 3.80 & High \\
\hline & & & ean & & & & & 3.01 & Fair \\
\hline X2.1 & $\begin{array}{l}\text { The salary accepted } \\
\text { is appropriate }\end{array}$ & 0 & 24 & 84 & 31 & 4 & 143 & 2.90 & Fair \\
\hline $\mathrm{X} 2.2$ & $\begin{array}{l}\text { The salary accepted } \\
\text { motivates to work }\end{array}$ & 3 & 41 & 72 & 23 & 4 & 143 & 3.11 & Fair \\
\hline $\mathrm{X} 2.3$ & $\begin{array}{l}\text { The allowances } \\
\text { accepted such as } \\
\text { TPB and ULP are } \\
\text { appropriate }\end{array}$ & 45 & 72 & 23 & 3 & 0 & 143 & 4.11 & High \\
\hline X2.4 & Religious holiday & 20 & 36 & 2 & 37 & 48 & 143 & 2.60 & Low \\
\hline
\end{tabular}




\begin{tabular}{|c|c|c|c|c|c|c|c|c|c|}
\hline & $\begin{array}{l}\text { allowance (THR) is } \\
\text { paid every year }\end{array}$ & & & & & & & & \\
\hline $\mathrm{X} 2.5$ & $\begin{array}{l}\text { Incentives motivate } \\
\text { to work }\end{array}$ & 30 & 108 & 2 & 2 & 1 & 143 & 4.15 & High \\
\hline \multicolumn{8}{|c|}{ Mean } & 3.37 & Fair \\
\hline X3.1 & $\begin{array}{l}\text { The work } \\
\text { surrounding is } \\
\text { comfortable and } \\
\text { clean }\end{array}$ & 0 & 10 & 88 & 45 & 0 & 143 & 2.76 & Fair \\
\hline X3.2 & $\begin{array}{l}\text { There is a sense of } \\
\text { security during work }\end{array}$ & 0 & 12 & 83 & 48 & 0 & 143 & 2.75 & Fair \\
\hline X3.3 & $\begin{array}{l}\text { Security at the place } \\
\text { of work is in place }\end{array}$ & 0 & 45 & 88 & 10 & 0 & 143 & 3.24 & Fair \\
\hline X3.4 & $\begin{array}{l}\text { The cooperation } \\
\text { between employees } \\
\text { is well established }\end{array}$ & 5 & 36 & 97 & 5 & 0 & 143 & 3.29 & Fair \\
\hline X3.5 & $\begin{array}{l}\text { The employee } \\
\text { receives fair } \\
\text { treatments }\end{array}$ & 1 & 32 & 89 & 21 & 0 & 143 & 3.09 & Fair \\
\hline X3.6 & $\begin{array}{l}\text { There is a good } \\
\text { relationship } \\
\text { between employees }\end{array}$ & 0 & 3 & 73 & 47 & 20 & 143 & 2.41 & Low \\
\hline X3.7 & $\begin{array}{l}\text { A good congenial } \\
\text { relationship is } \\
\text { established }\end{array}$ & 0 & 11 & 64 & 45 & 23 & 143 & 2.44 & Low \\
\hline X3.8 & $\begin{array}{l}\text { The office provides } \\
\text { facilities and } \\
\text { infrastructure }\end{array}$ & 0 & 20 & 51 & 45 & 27 & 143 & 2.45 & Low \\
\hline X3.9 & $\begin{array}{l}\text { There is a fairly } \\
\text { good air ventilation } \\
\text { in place }\end{array}$ & 12 & 106 & 23 & 2 & 0 & 143 & 3.90 & High \\
\hline X3.10 & $\begin{array}{l}\text { The temperature of } \\
\text { the interior is } \\
\text { conducive }\end{array}$ & 15 & 91 & 30 & 7 & 0 & 143 & 3.80 & High \\
\hline \multicolumn{8}{|c|}{ Mean } & 3.01 & Fair \\
\hline Y.1 & $\begin{array}{l}\text { The quality of the } \\
\text { work outcomes is } \\
\text { in compliance with } \\
\text { the standard }\end{array}$ & 4 & 60 & 71 & 8 & 0 & 143 & 3.42 & High \\
\hline Y.2 & $\begin{array}{l}\text { Tasks are completed } \\
\text { as targeted }\end{array}$ & 5 & 79 & 56 & 3 & 0 & 143 & 3.60 & High \\
\hline Y.3 & $\begin{array}{l}\text { The work } \\
\text { outcomes are good }\end{array}$ & 15 & 78 & 47 & 3 & 0 & 143 & 3.73 & High \\
\hline Y.4 & $\begin{array}{l}\text { The work is } \\
\text { performed based } \\
\text { on calculation }\end{array}$ & 3 & 62 & 77 & 1 & 0 & 143 & 3.47 & High \\
\hline Y.5 & My work outcomes & 0 & 60 & 75 & 8 & 0 & 143 & 3.36 & High \\
\hline
\end{tabular}




\begin{tabular}{llllllllll}
\hline \multicolumn{1}{c}{$\begin{array}{l}\text { meet the leaders' } \\
\text { expectations }\end{array}$} & \multicolumn{10}{c}{0} & & & & & & & \\
\hline Y.6 & $\begin{array}{l}\text { I arrive at the } \\
\text { office on time }\end{array}$ & 7 & 37 & 99 & 0 & 0 & 143 & 3.36 & Fair \\
\hline Y.7 & $\begin{array}{l}\text { I complete my work } \\
\text { in a timely manner }\end{array}$ & 0 & 68 & 74 & 1 & 0 & 143 & 3.47 & High \\
\hline Y.8 & $\begin{array}{l}\text { I am committed } \\
\text { and responsible }\end{array}$ & 0 & 76 & 65 & 1 & 1 & 143 & 3.51 & High \\
\hline & Mean & & & & & $\mathbf{3 . 4 9}$ & High \\
\hline
\end{tabular}

Note: $\mathrm{VG}=$ Very Good; $\mathrm{G}=$ Good; F = Fair; $\mathrm{B}=$ Bad; VB = Very Bad; X1 = Motivation; $\mathrm{X} 2$ = Compensation; $\mathrm{X} 3$ = Work Environment; $\mathrm{Y}=$ Employee Performance.

Based on the respondents' opinions distribution, the overall judgment of the respondents was that motivation, compensation, and work environment had moderate effects on employee performance. This was as shown by the means scored-3.01, 3.37, 3.00 , and 3.49, respectively-which belonged to the fair and high categories. The total mean of the respondents' answers regarding motivation, compensation, and work environment was in the fair category and thus in need of improvement.

Table 3. Results of Validity and Reliability Tests

\begin{tabular}{lcc}
\hline Item & R Hitung & Cronbach's Alpha \\
\hline X1.1 & 0.558 & \\
X1.2 & 0.504 & \\
X1.3 & 0.702 & \\
X1.4 & 0.680 & \\
X1.5 & 0.742 & \\
X1.6 & 0.657 & \\
X1.7 & 0.710 & \\
X1.8 & 0.776 & \\
X1.9 & 0.320 & \\
X1.10 & 0.238 & \\
X2.1 & 0.661 & \\
X2.2 & 0.705 & \\
X2.3 & 0.712 & \\
X2.4 & 0.798 & \\
X2.5 & 0.247 & \\
X3.1 & 0.391 & \\
X3.2 & 0.635 & \\
X3.3 & 0.661 & \\
X3.4 & 0.569 & \\
X3.5 & 0.389 & \\
X3.6 & 0.572 & \\
X3.7 & 0.558 & \\
X3.8 & 0.366 & \\
X3.9 & 0.433 & \\
X3.10 & 0.430 & \\
\hline
\end{tabular}




\begin{tabular}{lll}
\hline Y.1 & 0.729 & \\
Y.2 & 0.802 & \\
Y.3 & 0.859 & \\
Y.4 & 0.801 & 0.885 \\
Y.5 & 0.663 & \\
Y.6 & 0.689 & \\
Y.7 & 0.742 & \\
Y.8 & 0.672 & \\
\hline
\end{tabular}

Validity test was used to figure out the similarity between the data collected and the actual data in the objects investigated. The test was conducted by correlating the score of each item with the product moment correlation formula. According to the validity test results, all statements had $\mathrm{r}$ count values greater than 0.1642 , leading to a conclusion that all of the statements were valid. In addition, reliability test was also conducted by taking a look at the cronbach's alpha values. Reliability test was carried out to examine whether the instrument used was reliable to be used as a data collection instrument. The data testing results show that all the variables had cronbach's alpha values greater than 0.6 , leading to a conclusion that all the variables were reliable.

Table 4. Results of Classical Assumption Test

\begin{tabular}{|c|c|c|c|c|c|c|}
\hline \multicolumn{2}{|c|}{ Normality Test } & \multirow[b]{2}{*}{ Variable } & \multicolumn{2}{|c|}{ Multicollinearity Test } & \multicolumn{2}{|c|}{$\begin{array}{c}\text { Heteroscedasticity } \\
\text { Test }\end{array}$} \\
\hline $\begin{array}{l}\text { Kolmogorov } \\
\text { Smirnov }\end{array}$ & $\begin{array}{l}\text { Asymp. } \\
\text { Sig }\end{array}$ & & Tolerance & VIF & Sig Value & $\begin{array}{l}\text { Sig } \\
\text { Limit }\end{array}$ \\
\hline \multirow{3}{*}{0.055} & \multirow{3}{*}{0.200} & $\mathrm{X} 1$ & 0.733 & 1.364 & 0.251 & 0.05 \\
\hline & & $\mathrm{X} 2$ & 0.653 & 1.531 & 0.079 & 0.05 \\
\hline & & $\mathrm{X} 3$ & 0.706 & 1.416 & 0.121 & 0.05 \\
\hline
\end{tabular}

Classical assumption test was used to figure out whether there were residual normality, multicollinearity, and heteroscedasticity. Normality test was carried out to examine whether the residual values produced from the regression were normally distributed or not. This test was conducted using Kolmogorov Smirnov test. The result showed an Asymp. Sig value of 0.200, which was greater than 0.05, showing that the data were normally distributed.

Multicollinearity test was then used to examine whether within the regression model there was a correlation between the independent variables. The results show that all the independent variables had tolerance values greater than 0.1 and VIF values smaller than 10. It can thus be said that no multicollinearity occurred in each of the independent variables.

Lastly, heteroscedasticity test was used to figure out whether the independent variables exhibited homoscedasiticity or not. This test was conducted with Glejser test. From the results it was figured out that the sig. values of the three independent variables were upward of 0.05 . It can be said that no heteroscedasiticty problem existed in the regression model. (Table 5.) 
Table 5. Results of Multiple Regression Analysis and Hypotheses Testing

\begin{tabular}{|c|c|c|c|c|c|c|}
\hline \multirow{2}{*}{\multicolumn{2}{|c|}{ Model }} & \multicolumn{2}{|c|}{$\begin{array}{c}\text { Unstandardized } \\
\text { Coefficients }\end{array}$} & \multirow{2}{*}{$\begin{array}{c}\text { Standardized } \\
\text { Coefficients } \\
\text { Beta }\end{array}$} & \multirow[b]{2}{*}{$\mathrm{t}$} & \multirow[b]{2}{*}{ Sig. } \\
\hline & & $\mathrm{B}$ & Std. Error & & & \\
\hline$\overline{1}$ & (Constant) & 20,633 & 2,583 & & 7,987 & 0,000 \\
\hline & Motivation & $-0,068$ & 0,078 & $-0,079$ & $-0,872$ & 0,385 \\
\hline & Compensation & 0,535 & 0,116 & 0,442 & 4,631 & 0,000 \\
\hline & Work Environment & 0,010 & 0,092 & 0,010 & 0,111 & 0,912 \\
\hline & Adjusted $R$ Square & 0,154 & & & & \\
\hline
\end{tabular}

a. Dependant Variable: Performance

Based on Table 5, the multiple linear regression general equation is as follows:

$$
\begin{gathered}
\mathbf{Y}=\boldsymbol{\alpha}+\boldsymbol{\beta} 1 \mathbf{X} 1+\boldsymbol{\beta 2 X} \mathbf{2}+\boldsymbol{\beta 3 X} \mathbf{3} \\
\mathrm{Y}=20.633-0.068 \mathrm{X} 1+0.535 \mathrm{X} 2+0.010 \mathrm{X} 3
\end{gathered}
$$

The equation above can be interpreted as follows:

1. The constant $(\alpha)=20.633$ denotes that if motivation (X1), compensation (X2), and work environment (X3) were held constant, the value of employee performance (Y) would be 20.633. In other words, without the presence of the independent variables (X1, X2, X3), the value of employee performance (Y) would remain at 20.633.

2 . The coefficient value of the variable motivation $(\beta 1 \mathrm{X} 1)$ was -0.068 . With a negative mark, this coefficient would mean that for every increase of a motivation unit employee performance would decrease by 0.068 , with the assumption that the variables compensation and work environment that were investigated using the regression model in this research had constant values.

3. The coefficient value of the variable compensation $(\beta 2 \mathrm{X} 2)$ was 0.535 . With a positive mark, this coefficient would mean that for every increase of a compensation unit employee performance ( $\mathrm{Y}$ ) would increase by 0.535 , with the assumption that the variables motivation (X1) and work environment (X3) that were investigated using the regression model in this research had constant values.

4. The coefficient value of the variable work environment $(\beta 3 X 3)$ was 0.010 . With a positive mark, this coefficient would mean that for every increase of a work environment unit employee performance $(Y)$ would increase by 0.010 , with the assumption that the variables motivation (X1) and compensation (X2) that were investigated using the regression model in this research had constant values.

$\mathrm{T}$ test was then conducted to find out whether an independent variable had an effect on the dependent variable, with the assumption that every other variable was constant. The $\mathrm{t}$ count resulted for the variable motivation was -0.872 , while the sig. value was 0.385 . Given that the sig. value of 0.385 was greater than 0.05 , it would mean that motivation did not have any significant influence on the performance of local public officers in the Yapen Islands Regency. Hence, the first hypothesis stating that motivation has a positive effect on the performance of local public officers in the Yapen Islands Regency was rejected.

The finding above did not go in line with the research by Candradewi and Wahyudi et al. (2020), Wardani and Riyanto (2019), Dewi (2019), Marcy et al. (2018), and Suharno et al. (2017), which stated that motivation had a positive effect on employee performance, but it did agree with the research by Dharmanegara et al. (2016). Motivation did not have any significant effect on employee performance.

These testing results are consistent with the fact in the field and with the researchers' observation that there was still no appreciation given for the work and that the relationship 
established with the leaders was still not optimal. The work of an employee was restricted by the policies made by the higher-ups. For example, there were some class II employees who were not given any training facility for their self-development, inhibiting them from working optimally. This certainly shows that no significant effect was exerted on the performance of local public officers.

For the variable compensation, the $t$ count obtained was 4.631 , while the sig. value was 0.000 . This sig value was smaller than 0.05 , meaning that compensation partially had a significant effect on performance. Hence, the second hypothesis stating that compensation has a positive effect on the performance of local public officers of the Yapen Islands Regency was accepted.

This finding is in line with the previous research by Mukhlidah and Aktif (2020), Akbar et al. (2020), Candradewi and Dewi (2019), and Kadarisman (2019), which stated that compensation had a significant positive effect on local public officers performance. Compensation, both non-financial and financial, is one of the factors that support the increase of employee performance. Employees would work well if they receive fair compensation according to the main tasks and responsible assigned by their leaders. In other words, a good compensation system would give employees satisfaction, motivating them to improve their performance. The compensation referred to in this research was the financial compensation received by local public officers in the Yapen Islands Regency, including salary, uang lauk pauk, TPB (supplemental conditional income), and THR (religious holiday allowance).

Based on the results of the field data analysis, compensation had a significant positive effect on local public officers performance. Put otherwise, the compensation received by local public officers in the Yapen Islands Regency had a significant positive effect on their performance.

As for the variable work environment, the t count was 0.111 , and the sig. value was 0.912 . Given that the sig. value was greater than 0.05 , then it means that work environment did not partially have any significant effect on performance. Thus, the third hypothesis stating that work environment has a positive effect on the performance of local public officers of the Yapen Islands Regency was rejected. This finding is at odds with previous research by Wahyudi et al. (2020), Diamantidis and Prodromos (2019), Prabowo et al. (2019), Kurniawan and Heryanto (2019), and Wardani and Riyanto (2019), which stated that work environment had a positive effect on employee performance.

Based on the researchers' observation, this insignificance stemmed from the fact that the office had yet to provide sufficient facilities and infrastructure like laptops and computers that could support the local public officers in completing their works. Some were even not provided with desks and chairs. This insignificant value indicates that whether the environment where they worked good or not did not have any significant role in improving their performance.

Lastly, $\mathrm{R}^{2}$ value (coefficient of determination) was used to measure the ability of the variables motivation (X1), compensation (X2), and work environment (X3) to explain the variation in the variable e-government implementation (Y). From the test, an adjusted Rsquared value of 0.154 was obtained. This means that $15.4 \%$ of the variable local public officers performance was influenced by the independent variables motivation, compensation, and work environment. The remaining $84.6 \%$ of the variation was influenced by variables unexplored in this research. 


\section{Conclusion}

From the results of the tests that were conducted, the following conclusions were drawn: (1) motivation did not have any significant effect on the performance of local public officers in the Yapen Islands Regency; (2) compensation had a significant positive effect on the performance of local public officers in the Yapen Islands Regency; and (3) work environment did not have any significant effect on the performance of local public officers in the Yapen Islands Regency.

The empirical findings offer a number of critical implications for the best practice in the environment of the local government agencies in the Yapen Islands Regency. Based on the research results, the researchers suggested that the local government agencies in the Yapen Islands Regency should improve the employee performance by improving the motivation of the existing employees through giving appreciation for a work achievement and/or providing training facility for the employee's self-development. The improvement of employee performance should take work environment into consideration, in this case by providing supporting facilities and infrastructure for work completion like laptops, computers, desks and chairs, and a comfortable work atmosphere. Furthermore, attention should be directed toward the compensation system, which should comply with the principle of fairness and should be given in an appropriate amount so that the employees improve their performance.

\section{References}

Arif, S., et al. (2019). Influence of Leadership, Organizational Culture, Work Motivation, and Job Satisfaction of Performance Principles of Senior High School in Medan City. Budapest International Research and Critics Institute-Journal (BIRCI-Journal). P. 239-254.

Akbar, R., Musnadi, S., \& Putra, T. R. I. (2020). The Effect of Organizational Commitment, Emotional Intelligence and Compensation on Performance of Satpol PP and WH Aceh Employee Through Job Satisfaction. International Journal of Scientific and Management Research, 3(3), 8-22.

As'ad, M. (2004). Psikologi Industri: Seri ilmu Sumber Daya Manusia. Penerbit Liberty.

Bakhri, S., Modding, B., Gani, A., \& Lamo, M. (2015). Linking leadership style, work environment, job characteristics to civil servants performance: the mediating role of job satisfaction. International Journal of Humanities and Social Science Invention ISSN (Online), 2319-7722.

Candradewi, I., \& Dewi, I. G. A. M. (2019). Effect of compensation on employee performance towards motivation as mediation variable. International Research Journal of Management, IT and Social Sciences, 6(5), 134-143.

Davis, K., \& Newstrom. (1995). Perilaku dalam Organisasi. Erlangga.

Dharmanegara, I. B. A., Sitiari, N. W., \& Adelina, M. E. (2016). The impact of organizational commitment, motivation and job satisfaction on civil servant job performance in State Plantation Denpasar. Journal of Business and Management, 18(2), 41-50.

Dhermawan, A., Sudibya, I. G. A., \& Utama, I. W. M. (2012). Pengaruh motivasi, lingkungan kerja, kompetensi, dan kompensasi terhadap kepuasan kerja dan kinerja pegawai di lingkungan kantor Dinas Pekerjaan Umum Provinsi Bali. Jurnal Manajemen, Strategi Bisnis, Dan Kewirausahaan, 6(2), 173-184.

Diamantidis, A. D., \& Prodromos, C. (2019). Factors affecting employee performance: an 
empirical approach. International Journal of Productivity and Performance Management, 68(1), 171-193. https://doi.org/10.1108/IJPPM-01-2018-0012

Greenberg, J., \& Baron, R. (2003). Behavior in Organizations Understanding and Managing the Human Side of Work. Prentice-Hall International.

Hasibuan, M. (2014). Manajemen Sumber Daya Manusia. Bumi Aksara.

Jacobsen, C. B., Hvitved, J., \& Andersen, L. B. (2014). Command and motivation: How the perception of external interventions relates to intrinsic motivation and public service motivation. Public Administration, 92(4), 790-806.

Kadarisman, M. (2019). The influence of compensation, development, and supervision towards the performance of civil servants in depok city government, Indonesia. Cogent Psychology, 6(1), 1620402.

Kreitner, R., \& Kinicki, A. (2001). Organizational Behavior (15th ed.). McGraw-Hill Companies.

Kuranchie-Mensah, E. B., \& Amponsah-Tawiah, K. (2016). Employee motivation and work performance: A comparative study of mining companies in Ghana. Journal of Industrial Engineering and Management (JIEM), 9(2), 255-309.

Kurniawan, H., \& Heryanto, H. (2019). Effect of Work Discipline and Work Environment on Employee Performance with Work Motivation as an Intervening Variable in Department of Tourism, Youth and Sport of Padang District. Archives of Business Research, 7(7), 88-101.

Kusriyanto, B. (1991). Meningkatkan Produktivitas Karyawan. PT. Pustaka Binaman Pressindo.

Kusumayuda, H. (2019). The Effect of Performance Appraisal Systems and Compensation Systems on Work Motivation Mediated by Job Satisfaction of Yogyakarta Primary Tax Service Office Employees. International Journal of Innovative Research and Development, 8(9). https://doi.org/10.24940/ijird/2019/v8/i9/sep19040

Lee, S. Y., \& Brand, J. L. (2005). Effects of control over office workspace on perceptions of the work environment and work outcomes. Journal of Environmental Psychology, 25(3), 323-333.

Marcy, R., Otto, R. P., Yohanes, R., Ruben, T., \& Anita, E. (2018). Moderating effect of organizational citizenship behavior on the effect of organizational commitment, transformational leadership and work motivation on employee performance. International Journal of Law and Management, 60(4), 953-964. https://doi.org/10.1108/IJLMA-03-2017-0026

Martoyo, S. (2007). Manajemen Sumber Daya Manusia. BPFE Yogyakarta.

Marwansyah. (2014). Manajemen Sumber Daya Manusia (2nd ed.). Alfabeta.

Mathis, R. L., \& Jackson, J. H. (2006). Human Resource Management: Manajemen Sumber Daya Manusia. Salemba Empat.

Mukhlidah, S., \& Aktif, N. (2020). The Influence of Training, Motivation and Compensation Against Employee Performance on Procurement Center At Dki Jakarta. Dinasti International Journal of Education Management And Social Science, 2(1), 150-161.

Mukti, T. P. (2015). Pengaruh Lingkungan Kerja, Kompensasi, dan Motivasi Terhadap Kinerja Pegawai Negeri Sipil di Rumah Sakit Daerah Madani Propinsi Sulawesi Tengah. Katalogis, 3(6).

Murni, M., \& Heryanto. (2019). The Effect Of Compensation, Motivation And Work Satisfaction To The Performance At Investment And Integrated One-Stop Service Office Regency Of Dharmasraya. Archives of Business Research, 7(8), 57-65.

Mustafid, H. (2017). Peningkatan Kinerja Aparatur Sipil Negara melalui Budaya 
Organisasi. Tarbawi: Jurnal Keilmuan Manajemen Pendidikan, 3(01), 1-14.

Ningsih, S. (2018). The Relationship Between Motivation and Worker's Productivity in Civil Registration and Population Department, Asahan Regency, Indonesia. Budapest International Research and Critics Institute-Journal (BIRCI-Journal). P. 148-160

Nitisemito, A. S. (2005). Manajemen Personalia (5th ed.). Ghalia Indonesia.

Permadi, B., Dharmanegara, I. B. A., \& Sitiari, N. W. (2018). The Effects Of Leadership And Motivation Againsts Work Discipline And Performance Of Civil Servant Employees At Balai Wilayah Sungai Bali Penida. Jurnal Ekonomi \& Bisnis JAGADITHA, 5(1), 46-57.

Prabowo, B. H., Puspaningtyas, M., \& Murniati, M. (2019). Analysis of The Influence of Competence, Work Environment, and Work Discipline on The Performance of The Staff of The Regional Civil Service Agency in Malang City. Review of Behavioral Aspect in Organizations and Society, 1(2), 141-148.

Renstra Kabupaten Kepulauan Yapentahun 2020 Nomor Renstra - 02/Lap.Knja ASN /28/04/2020

Republik Indonesia. Peraturan Pemerintah Republik Indonesia Nomor 35 Tahun 2019 Perubahan Ketiga Atas Peraturan ketiga Atas Peraturan Pemerintah Nomor 19 Tahun 2016 Tentang pemberian gaji,Pensiun,atau Tunjangan Ketiga Belas Kepada Aparatur Sipil Negara.

Republik Indonesia. Undang-Undang Nomor 43 Tahun 1999 tentang Pokok-Pokok Kepegawaian.

Republik Indonesia. Undang-Undang Nomor 5 Tahun 2014 tentang Aparatur Sipil Negara Pasal 79.

Rivai, V., \& Sagala, J. (2005). Manajemen Sumber Daya Manusia Untuk Perusahaan. PT. Raja Grafindo Persada.

Sedarmayanti. (2009). Sumber Daya Manusia dan Produktivitas Kerja. CV Mandar Maju.

Sudrajat, T., Kunarti, S., \& Hartini, S. (2019). Bridging The Legal Gap Between Open Selection and Internal Selection of State Civil Apparatus Promotion In Indonesia. IOP Conference Series: Earth and Environmental Science, 255(1), 12053.

Sugiyono. (2013). Metode Penelitian Kuantitatif, Kualitatif dan R\&D. Alfabeta.CV.

Suharno, P., Katijan, S. P., \& Muzaffar, M. (2017). Factors affecting employee performance of PT.Kiyokuni Indonesia. International Journal of Law and Management, 59(4), 602-614. https://doi.org/10.1108/IJLMA-03-2016-0031

Wahyudi, W., Semmaila, B., \& Arifin, Z. (2020). Influences of work discipline, motivation and Working Environment Non physical on Civil apparatus Performance. Point Of View Research Management, 1(3), 1-8.

Wardani, B. D. P., \& Riyanto, S. (2019). The Influence of Motivation, Discipline and Work Environment on the Performance of The Inspectorate of Government Internal Supervisory Apparatus Bekasi District. International Journal of Innovative Science and Research Technology, 4(5).

Widasih, E., Arisyahidin, A., \& Sumarji, S. (2019). Analisis Pengaruh Kompensasi terhadap Kepuasan Kerja Pegawai Negeri Sipil Dinas Pendidikan Kota Blitar. REVITALISASI: Jurnal Ilmu Manajemen, 6(1), 40-46.

Wirawan. (2009). Evaluasi Kinerja Sumber Daya Manusia Teori Aplikasi dan Penelitian. Salemba Empat. 